\title{
FAKTOR-FAKTOR YANG MEMPENGARUHI STRUKTUR MODAL PADA PERUSAHAAN OTOMOTIF YANG TERDAFTAR DI BURSA EFEK INDONESIA
}

\author{
Nur Istiqomah, Aminar Sutra Dewi \\ Sekolah Tinggi Ilmu Ekonomi KBP \\ muttiara94@yahoo.com
}

\begin{abstract}
This assessment intends to analyze the factors affecting the capital structure. Automotive companies must have optimal capital and maximum corporate finance in order to obtain satisfactory results and avoid bankruptcy. The purpose of this study is to determine the effect of firm size on the capital structure, the influence of liquidity on the capital structure and the effect of profitability on the capital structure listed on the Indonesia Stock Exchange with a two-year study period, 2013 to 2016. With a sample of six companies, using a proposive sampling. The analysis method used is multiple linear regression analysis. The results showed that firm size did not have a positive and insignificant effect on capital structure, liquidity had positive and insignificant effect on capital structure, and profitability had no positive and insignificant effect on capital structure. Because profitability had increased, there is a decrease for long-term debt repayment.
\end{abstract}

Keywords: capital structure, firm size, liquidity, profitability.

\section{PENDAHULUAN}

Persaingan yang kompetitif menjadikan tugas manajer keuangan semakin berat yaitu mencari alternatif pendanaan yang bisa meminimalkan angaran modal hal itu harus dilakukan prusahaan agar dapat menentukan struktur angaran dana yang di imbangi malalui manajemen strutur modal. Teori struktur modal menerangkan hubungan apakah tersedianya beberapa penghasil dana serta pembiayaan modal berbeda mempunyai pengaruh pergantian struktur modal terhadap biaya modal dan nilai prusahaan.

Tingkat pemulihan investor berdana pada pengeluaran biaya modal perusahaan. Perusahaan untuk melanjutkan bisnis dan usahanya memerlukan dana, dana dihasilkan oleh yang punya perusahaan atau pun hutang mendapatkan penambahan dana dari luar juga dapat menolong prusahaan. Keputusan pendanaan adalah keputusan seberapa besar pemakaian hutang daripada ekuitas untuk pembiayaan investasi sehingga meningkatkan nilai perusahaan. Karena permasalahan pendanaan merupakan hal paling utama untuk sebuah perusahaan, jadi perusahaan otomotif harus mempunyai pemodalan yang tinggi dan keuangan perusahaan yang maksimal dan jauh dari kerugian agar tidak tersendat dan supaya mendapatkan hasil. Seperti halnya pada perusahaan General Motor Indonesia (GMI) yang mengalami kebangkrutan dikarenakan kurangnya pendanaan untuk mengikuti trend atau model terkini dan kalah persaingaan 
sehinggan mengakibatkan merosotnya penjualan berbagai produk otomotif buatannya,karena turunnya harga komoditas atau merosotnya perekonomian akan menyebabkan kekalahan dalam persaingan bisnis.

Struktur modal di perusahaan otomotif sekarang ini masih naik turun (Fluktuasi) karena persaingan ketat dan mengikuti perkembangan teknologi. penelitian pada struktur modal ini memakai alat ukur untuk menghitung struktur modal adalah Debt to Equity Ratio (DER) yaitu diantara total hutang dan modal sendiri dalam struktur finansial perusahaan. Adapun data nilai DER untuk perusahaan manufaktur untuk sektor industri otomotif tahun 2016 tertera pada tabel 1 berikut :

Tabel 1

Data DER Perusahaan Otomotif tahun 2016

\begin{tabular}{|c|c|c|}
\hline No & $\begin{array}{c}\text { Nama Perusahaan Otomotif yang Terdaftar di BEI } \\
\text { \% }\end{array}$ & DER \\
\hline 1. & ASII (Astra International Tbk) & 0.87 \\
2. & AUTO (Astra Oto Part Tbk) & 0.39 \\
3. & BRAM (Indo Kordsa Tbk) & 0.50 \\
4. & GDYR (Goodyear Indonesia Tbk) & 0.01 \\
5. & INDS (Indospring Tbk) & 0.20 \\
6. & SMSM (Selamat Sampurna Tbk) & 0.43 \\
\hline
\end{tabular}

Sumber : Bursa Efek Indonesia 2016 (www.idx.co.id)

Berdasarkan tabel diatas 1, dapat dipahami pergerakan struktur modal perusahaan otomotif yang termasuk di dalam Bursa Efek Indonesia. Terdapat peningkatan dan penurunan (fluktuasi) rasio DER, yaitu dapat di perhatikan pada perusahaan GDYR (goodyear Indonesia Tbk) memiliki nilai DER terendah sebesar $0,01(<1)$, hal ini berati bahwa kegiatan perusahaan banyak didanai oleh modal dari pada hutang dan perusahaan tersebut dipandang dapat melunasi semua utang jangka panjangnya. Adapun perusahaan dengan nilai DER tertinggi yaitu sebesar 8,26 (>2) pada perusahaan Multi Prima Sejahtera Tbk (LPIN), maka hutang banyak digunakan untuk mendanai operasi perusahaan dibandingkan modal dan akan mengusik kenaikan harga sahamnya karena sebagian investor menjauhi perusahaan dengan angka DER yang tinggi.

Besar kecilnya perusahaan adalah ukuran perusahaan diamana perusahaan besar gampang memperoleh pinjaman dari luar, baik hutang ataupun modal saham sebab perusahaan besar memiliki reputasi baik bagi masyarakat (Wimelda dan marlinah, 2013) dalam (Bhawa \& S, 2015). Ukuran Perusahaan (size) adalah faktor yang dipakai sebagai perimbangan untuk menetapkan struktur modal. Penggunaan hutang adalah salah satu usaha agar memperoleh keperluan pendanaan dan perusahaan besar memiliki keperluan modal besar sebagai pembayaran aktivitas perusahaan. Menurut Asymmetric information theory menyatakan rendahnya pengetahuan tentang informasi pada perusahaan besar daripada perusahaan kecil. Perusahaan besar mendapat perolehan biaya ekuitas sangat sedikit dari pada perusahaan kecil, sehingga perusahaan besar banyak menggunakan ekuitas dibandingkan perusahaan kecil. Dengan demikian perusahaan yang berukuran skala besar lebih banyak pendanaan dari banyak sumber, sehingga prusahaan besar lebih gampang mendapakan pemodalan dari kreditur sebab mempunyai profitabilitas besar supaya menjadi pemenang pada persaingan industri. 
Perusahaan dengan ukuran besar sering memakai hutang untuk memperbesar struktur modalnya, sedangkan perusahaan dengan skala kecil sedikit memakai hutang sehingga memperkecil struktur modal perusahaan. Perhitungan skala perusahaan (firm Size) pengkajian ini menggunakan total asset yaitu pada laporan keuangan perusahaan.

Likuiditas adalah kesanggupan perusahaan untuk mendanai kemampuan finansial utangnya tepat waktu (Sartono, 2010:116) dalam (Bhawa \& S, 2015). Menurut pecking order theory, perusahaan besar dengan likuiditas tinggi jarang memakai pembiayaan dari pinjaman hutang. Perusahaan dengan likuiditas banyak mempunyai dana internal perusahaan yang besar, sehingga perusahaan memakai dana internal perusahaannya dahulu untuk membayar investasinya sebelum memakai pembayaran eksternal perusahaan melalui hutang. Perusahaan yang mempunyai likuiditas banyak berarti perusahan yang bisa bayar hutang sehinga nilai hutang akan cepat terlunasi yang bisa menjadikan struktur modal turun.

Ukuran perusahaan adalah suatu ukuran perusahaan yang dilihat pada besarnya aktiva perusahaan (Wimelda dan Marlinah, 2013) dalam (Primantara \& Dewi, 2016). Penelitian yang dilakukan oleh (Sansoethan \& Suryono, 2016) tentang Faktor-Faktor yang mempengaruhi struktur modal pada perusahaan makanan dan minuman mengemukakan bahwa ukuran perusahaan berpengaruh positif terhadap struktur modal. Penelitian yang dilakukan oleh (Ichwan \& Widyawati, 2015) tentang pengaruh ukuran perusahaan, struktur aktiva dan profitabilitas terhadap struktur modal mengemukakan bahwa ukuran perusahaan berpengaruh positif pada struktur modal.

Penelitian yang dilakukan (Primantara \& Dewi, 2016) tentang pengaruh likuiditas, profitabilitas, risiko bisnis, ukuran perusahaan, dan pajak terhadap struktur modal membuktikan bahwa ukuran perusahaan berpengaruh positif dan signifikan terhadap struktur modal. Dan penelitian yang dilakukan (Bhawa \& S, 2015) tentang pengaruh ukuran perusahaan, likuiditas, profitabilitas, dan risiko bisnis terhadap struktur modal perusahaan farmasi menyatakan bahwa ukuran perusahaan berpengaruh positif signifikan terhadap struktur modal. Maka hipotesis pertama diduga ukuran perusahaan berpengaruh positif dan signifikan terhadap struktur modal.

Likuiditas perusahaan merupakan kekuatan perusahaan untuk membayar kewajibannya yang jatuh tempo pada waktu yang ditentukan. Likuiditas merupakan kesanggupan perusahaan membiayai kesanggupan finansial jangka pendek tepat waktu (Sartono, 2010:116) dalam (Bhawa \& S, 2015). Penelitian oleh (Hudan et al., 2016) tentang Pengaruh Profitabilitas, Likuiditas dan Ukuran Perusahaan terhadap Struktur Modal (Studi pada Perusahaan Pertambangan Sektor Batubara yang terdaftar di Bursa Efek Indonesia Tahun 2011 - 2015) membuktikan bahwa likuiditas berpengaruh negatif terhadap struktur modal.

Penelitian yang dilakukan (Primantara \& Dewi, 2016) tentang Pengaruh Likuiditas, Profitabilitas, Risiko bisnis, Ukuran Perusahaan, dan Pajak terhadap Struktur Modal menyatakan bahwa likuiditas berpengaruh negatif dan signifikan terhadap struktur modal. Dan penelitian yang dilakukan (Bhawa \& S, 2015) tentang pengaruh ukuran perusahaan, likuiditas, profitabilitas, dan risiko bisnis terhadap struktur modal perusahaan farmasi membuktikan bahwa likuiditas berpengaruh negatif signifikan terhadap struktur modal. Maka hipotesis kedua diduga likuiditas berpengaruh negatif dan signifikan terhadap struktur modal. 
Profitabilitas adalah kesanggpuan perusahaan dalam mendapatkan laba. Sedangkan menurut Riyanto (2007:331) dalam (Ichwan \& Widyawati, 2015) rasio-rasio profitabilitas yaitu rasio-rasio yang menunjukkan hasil akhir dari sejumlah kebijaksanaan dan keputusan-keputusan. Penelitian oleh (Hudan et al., 2016) tentang pengaruh profitabilitas, likuiditas dan ukuran perusahaan pada struktur modal (studi pada perusahaan pertambangan sektor batubara yang terdaftar di Bursa Efek Indonesia Tahun 2011 - 2015) membuktikan bahwa profitabilitas berpengaruh negatif terhadap struktur modal.

Penelitian yang dilakukan (Bhawa \& S, 2015) tentang pengaruh ukuran perusahaan, likuiditas, profitabilitas, dan risiko bisnis terhadap struktur modal perusahaan farmasi menyatakan bahwa profitabilitas berpengaruh negatif signifikan terhadap struktur modal. Penelitian yang dilakukan (Primantara \& Dewi, 2016) tentang pengaruh likuiditas, profitabilitas, risiko bisnis, ukuran perusahaan, dan pajak terhadap struktur modal membuktikan bahwa profitabilitas berpengaruh negatif dan signifikan terhadap struktur modal. Maka hipotesis ketiga diduga profitabilitas berpengaruh negatif dan signifikan terhadap struktur modal.

\section{Kerangka Konseptual}

\section{Gambar 1}

Kerangka Konseptual

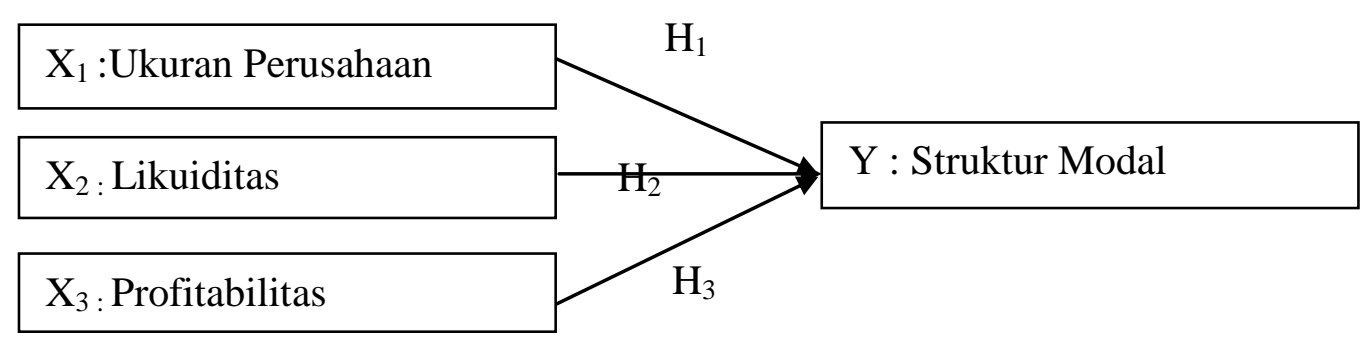

\section{METODE PENELITIAN}

Jenis penelitian pada penelitian ini adalah data kuantitatif. Penelitian kuantitatif adalah metode penelitian yang berdasarkan pada filsafat positivisme, yang digunakan peneliti pada populasi atau sampel tertentu, pengumpulan data memakai instrumen penelitian, analisis data bersifat kuantitatif atau statistik, bertujuan untuk menguji hipotesisi yang sudah ditetapkan (Sugiyono, 2015).

Menurut Sugiyono (2011:119) dalam (Hudan et al., 2016) populasi adalah daerah generalisasi yaitu obyek atau subyek yang memiliki kualitas dan karakteristik tertentu yang ditentukan peneliti agar dipelajari kemudian disimpulkan. Populasi pada pengkajian ini adalah perusahaan-perusahaan otomotif yang terdaftar di BEI tahun 2013 - 2016 yaitu 13 perusahaan.

Menurut Sekaran (2011:123) dalam (Hudan et al., 2016) sampel adalah bahagian dari populasi. Sampel terdiri atas sejumlah anggota yang dipilih dari populasi. Terdapat 13 perusahaan otomotif yang terdaftar di BEI, namun 7 perusahaan tidak dipakai sebagai sampel penelitian karena tidak mempunyai laba dan tidak mempublikasikan laporan keuangan pada tahun 2016. Dengan demikian hanya 6 perusahaan otomotif.

Pada pengkajian ini pengambilan sampel memakai tekhnik purposive sampling. Purposive sampling adalah teknik penentuan sampel dengan penilaian tertentu (Sugiyono, 2011:126) dalam (Hudan et al., 2016). Kriteria sampel pada pengkajian ini adalah : 
1. Sampel yang digunakan adalah Perusahaan Otomotif yang terdaftar di BEI tahun 2013 - 2016.

2. Perusahaan yang memplubikasikan laporan keuangan per 31 Desember yang lengkap secara terus - menerus terutama pada tahun 2013 - 2016.

3. Perusahaan yang mempunyai laba positif berturut - turut terutama pada tahun 2013 - 2016.

\section{Analisa Statistik Deskriptif}

Dipakai agar mendapatkan gambaran mengenai faktor - faktor yang mempengaruhi variabel, baik secara numerik contohnya menghitung rata - rata, standar deviasi berbentuk tabel atau grafik.

\section{Uji Asumsi Klasik}

1. Uji Normalitas Data

Uji normalitas adalah pengkajian apakah pada model regresi, variabel pengganggu berdistribusi normal atau tidak (Ghozali, 2006:110) dalam (Sansoethan \& Suryono, 2016) . Uji normalitas dipakai sebagai pengujian apakah sebuah model regresi, variabel dependen, variabel independen, dan keduanya berada pada distribusi normal atau tidak. Model regresi yang bagus adalah data distribusi normal dan merata. Untuk mendeteksi normalitas data pada pengkajian ini menggunakan uji kolmogorov-smirnov test. Pengujian ini agar mengetahui apakah sampel yang digunakan berdistribusi normal atau tidak. Jika analisis memakai metode parametrik maka data harus distribusi normal. Apabila data tidak berdistribusi normal, metode yang dipakai adalah statistik non parametrik.

2. Uji Multikolinearitas

Uji multikolinieritas yaitu hubungan sesama variabel bebas. Multikolinearitas adalah keadaan variabel - variabel independen pada persamaan regresi memiliki (hubungan) erat satu sama lain korelasi. Salah satu maksud dikerjakannya pengkajian ini adalah untuk pembuktian apakah antara variabel independen terjadi korelasi antara satu variabel dengan variabel lain.

3. Uji Heteroskedastisitas

Pengujian pada pengkajian ini memakai metode uji glejser, dimana metode uji glejser yaitu dangan meregresikan semua variabel bebas pada nilai mutlak residualnya, nilai signifikan uji glejser adalah $>0,05$ sebagai pengambilan keputusan.

4. Uji Autokorelasi

Uji autokerelasi digunakan untuk mendeteksi ada tidaknya autkorelasi, autokorelasi adalah korelasi yang terjadi diantara anggota - anggota dari beberapa pengamatan yang tersusun pada data time series Model penelitian yang bagus adalah tidak terjadi autokorelasi.

\section{Analisis Regresi Liner Berganda}

Pengkajian ini memakai program SPSS untuk memperoleh semua nilai yang diinginkan pada model analisis regresi dan pengkajian secara statistik. Persamaan regresi pengkajian ini adalah akan mebuktikan berapa kuatnya pengaruh variabel bebas terhadap variabel dependen disebabkan adanya variabel mediasi.

\section{Uji Hipotesis}

Akan mebuktikan apakah semua variabel independenya memang secara bersama - sama atau parsial memiliki pengaruh nyata terhadap variabel 
dependennya. Uji satistik adalah menguji apakah hasil yang dicapai sudah sesuai dengan metode - metode statistik, meliputi :

\section{Uji F (Simultan)}

Uji F dipakai untuk menguji pengaruh variabel independen yaitu Ukuran Perusahaan, Likuiditas dan Profitabilitas secara bersama - sama pada variabel dependen yaitu Struktur Modal.

\section{Uji t (Persial)}

Uji t dipakai sebagai pengujian pengaruh variabel independen secara persial pada variabel dependen yaitu akibat dari variabel independen (Ukuran Perusahaan, Likuiditas dan Profitabilitas) terhadap variabel dependen yaitu (Struktur Modal).

Pengujian juga bisa dilakukan melalui pengamatan nilai signifikansi t pada tingkat $\alpha$ yang digunakan ( pengkajian ini menggunakan tingkat $\alpha$ sebesar 5\% ).

\section{Analisis Koefisien Determinasi Multiple $\left(\mathbf{R}^{2}\right)$}

Nilai koefisien determinasi adalah antara nol dan 1 atau $(0<\mathrm{x}<1)$. Nilai adjusted R2 rendah artinya kesanggupan variabel-variabel independen untuk menjelaskan variabel-variabel dependen sangat terbatas. Koefisien determinasi (Adjusted R2) pada intinya menghitung seberapa jauh kesanggupan model untuk menetapkan perbedaan variabel dependen.

\section{HASIL PENELITIAN DAN PEMBAHASAN Gambaran Umum Obyek Penelitian}

Data pada pengkajian ini adalah data sekunder. Data sekunder adalah data yang didapatkan dari pihak kedua, ketiga dan seterusnya. Objek pada pengkajian ini adalah Perusahaan Otomotif yang terdaftar di Bursa Efek Indonesia (BEI) periode 2013 - 2016. Pada periode ini terdapat 13 perusahaan otomotif yang tercatat di BEI namun setelah dikerjakan Purposive Sampling untuk menentukan sampel penelitian, sampel yang baik digunakan (memenuhi kriteria) pada penelitian adalah 6 perusahaan otomotif.

\section{Deskriptif Variabel Penelitian}

Data statistik yang telah diolah dengan aplikasi SPSS yaitu pada tabel berikut :

Tabel 2

Statistik Deskriptif Variabel Penelitian

Descriptive Statistics

\begin{tabular}{lrrrrr}
\hline & N & \multicolumn{1}{c}{ Minimum Maximum } & Mean & Std. Deviation \\
\hline Ukuran Perusahaan & 24 & 12.27 & 28.57 & 18.8858 & 5.54424 \\
Likuiditas & 24 & .86 & 3.86 & 1.7967 & .77082 \\
Profitabilitas & 24 & .10 & 24.00 & 7.6879 & 6.92228 \\
Struktur Modal & 24 & .01 & 3.95 & .7442 & .75105 \\
Valid N (listwise) & 24 & & & & \\
\hline
\end{tabular}

Sumber: Data diolah dengan SPSS16

Tabel diatas menunjukkan laporan keuangan tahunan perusahaan otomotif yang terdaftar di Bursa efek Indonesia (BEI) bahwa jumlah data pada pengkajian ini adalah 24. 
Data dari variabel ukuran perusahaan (Zise) yang di hitung denga total asset yaitu Ln ( Tota Asset) menunjukkan hasil rata - rata sebesar 18.8858, nilai terendah (Min) variabel ini adalah 12,27. Perusahaan yang mempunyai nilai terendah atau ukuran perusahaan (Zise) yang sedikit adalah perusahaan Astra International Tbk (ASII) pada tahun 2013. Sedangkan untuk nilai tertinggi (Max) adalah 28.57. Adapun nilai tertinggi atau ukuran perusahaan terbanyak adalah perusahaan Indospring Tbk (INDS) pada tahun 2015. Untuk besarnya kesalahan (Standar Deviation) pada variabel ini adalah sebesar 5.54424.

Variabel likuiditas diukur dengan memakai rasio lancar Current Ratio (CR) menunjukkan hasil rata - rata sebesar 1.7967 dan besarnya kesalahan (Standar Deviation) sebesar 0.77082 untuk nilai terendah pada variabel ini adalah sebesar 0.86. Perusahaan dengan nilai terendah atau likuiditas yang kecil adalah perusahaan Goodyear Indonesia Tbk (GDYR) pada tahun 2016. Sedangkan untuk nilai tertinggi (Max) adalah 3.86. Adapun nilai tertinggi atau likuiditas terbanyak adalah perusahaan Indospring Tbk (INDS) pada tahun 2013.

Untuk variabel profitabilitas diukur dengan rasio profitabilitas Return on Asset (ROA) dengan hasil rata - rata sebesar 7,6879 dan besarnya kesalahan (Standar Deviation) sebesar 6,92228 untuk nilai terendah pada variabel ini adalah sebesar 0,10. Perusahaan dengan ROA terendah adalah perusahaan Indospring Tbk (INDS) pada tahun 2015. Sedangkan untuk nilai tertinggi (Max) adalah 24,00. Adapun ROA tertinggi adalah perusahaan Selamat Sampurna Tbk (SMSM) pada tahun 2014.

Variabel Strutur Modal yang dihitung dengan menggunakan Debt to Equity Ratio (DER) menunjukkan hasil rata - rata sebesar 0,7442 nilai terendah pada variabel ini adalah sebesar 0,01. Perusahaan dengan DER terendah adalah perusahaan Goodyear Indonesia Tbk (GDYR) pada tahun 2016. Sedangkan untuk nilai tertinggi (Max) adalah 3,95. Adapun DER tertinggi adalah perusahaan Indospring Tbk (INDS) pada tahun 2013. Dan besarnya kesalahan (Standar Deviation) sebesar 0,75105.

\section{Uji Asumsi Klasik}

\section{Uji Normalitas Data}

Normalitas dari masing - masing variabel dapat dilihat pada tabel dibawah ini :

Tabel 3

Hasil Uji Normalitas

One-Sample Kolmogorov-Smirnov Test

\begin{tabular}{lr}
\hline & Standardized Residual \\
\hline Kolmogorov-Smirnov Z & .697 \\
Asymp. Sig. (2-tailed) & .717 \\
\hline
\end{tabular}

Sumber: Data diolah dengan SPSS16

Dari tabel diatas dapat dilihat signifikan yang dihasilkan dari olahan data diatas lebih dari 0,05. Dimana nilai Asymp. Sig sebesar $0.717>0,05$. Sehingga disimpulkan semua data variabel berdistribusi normal .

\section{Uji Multikolinearitas}

Hasil uji multikolinearitas dari variabel - variabel yang dipakai dapat dilihat pada tabel dibawah ini : 


\section{Tabel 4}

Hasil Uji Multikolinearitas

\begin{tabular}{lrrl}
\hline \multicolumn{1}{c}{ Variabel } & Tolerance & \multicolumn{1}{l}{ VIF } & Keterangan \\
\hline Ukuran Perusahaan & .455 & 2.198 & Tidak Terjadi Multikoleniaritas \\
Likuiditas & .440 & 2.273 & Tidak Terjadi Multikoleniaritas \\
Profitabilitas & .625 & 1.601 & Tidak Terjadi Multikoleniaritas \\
\hline
\end{tabular}

Sumber: Data diolah dengan SPSS16

Berdasarkan tabel diatas dapat dilihat hasil dari olahan data tidak menunjukkan adanya korelasi antar variabel bebas (bebas multikolinearitas). Nilai VIF yang ditunjukkan masing - masing variabel adalah ukuran perusahaan sebesar 2.198, likuiditas sebesar 2.273 dan profitabilitas sebesar 1.601. Karena dasar pengambilan keputusan dengan VIF ini dikatakan tidak ada korelasi jika nilainya kecil dari 10.00, sedangkan nilai yang dihasilkan masing - masing variabel kecil dari 10,00 berarti tidak ada korelasi antara variabel - variabel tersebut. Jika dilihat dari nilai tolerance yang dihasilkan ketiga variabel juga menjelaskan bahwa tidak ada korelasi antar variabel - variabel tersebut, dimana nilai dari ketiga variabel tersebut lebih besar dari 0,10 yang menjadi standar pengukuran untuk torelance.

\section{Uji Heteroskedastisitas}

Hasil uji heteroskedastisitas dari variabel - variabel dapat dilihat pada tabel dibawah ini :

\section{Tabel 5}

\section{Hasil Uji Heteroskedatisitas}

\begin{tabular}{lcc}
\hline \multicolumn{1}{c}{ Variabel } & Sig. & Keterangan \\
\hline Ukuran Perusahaan & 0.154 & Tidak Terjadi Heteroskedastisitas \\
Likuiditas & 0.125 & Tidak Terjadi Heteroskedastisitas \\
Profitabilitas & 0.527 & Tidak Terjadi Heteroskedastisitas \\
\hline
\end{tabular}

Sumber : Data diolah dengan SPSS16

Berdasarkan output diatas dapat dilihat bahwa dari ketiga variabel diatas tidak ada gejala heteroskedastisitas karena nilai signifikan dalam pengujian Glejser adalah $>0,05$. Karena nilai signifikan yang dihasilkan masing - masing variabel lebih dari 0,05 dimana untuk variabel ukuran perusahaan sebesar 0,154, likuiditas sebesar 0,125 dan profitabilitas sebesar 0,527.

\section{Uji Autokorelasi}

Hasil uji autokorelasi dari variabel - variabel dapat dilihat pada tabel dibawah ini :

Tabel 6

Hasil Uji Autokorelasi

Model Summary ${ }^{\text {b }}$

\begin{tabular}{lrrrrr}
\hline Model & $\mathrm{R}$ & R Square & $\begin{array}{c}\text { Adjusted R } \\
\text { Square }\end{array}$ & $\begin{array}{l}\text { Std. Error of } \\
\text { the Estimate }\end{array}$ & \multicolumn{1}{c}{ Durbin-Watson } \\
\hline 1 & $.372^{\mathrm{a}}$ & .139 & .009 & .74750 & 2.146 \\
\hline
\end{tabular}

Sumber: Data diolah dengan SPSS16 
Berdasarkan output diatas terlihat bahwa nilai DW model regresi sebesar 2.146 Dikarenakan nilai DW berada pada DW 1,55 - 2,46 maka model ini diartikan tidak terjadi masalah autokorelasi.

\section{Analisis Regresi Linier Berganda}

Hasil analisis regresi linier berganda terdapat pada tabel berikut :

Tabel 7

Hasil Analisis Regresi Linear Berganda

\begin{tabular}{|c|c|c|c|c|c|c|}
\hline \multicolumn{7}{|c|}{ Coefficients $^{\mathrm{a}}$} \\
\hline & & $\begin{array}{r}\text { Unstand } \\
\text { Coeffic }\end{array}$ & $\begin{array}{l}\text { rdized } \\
\text { ients }\end{array}$ & $\begin{array}{l}\text { Standardized } \\
\text { Coefficients }\end{array}$ & & \\
\hline \multicolumn{2}{|c|}{ Model } & $\mathrm{B}$ & Std. Error & Beta & $\mathrm{t}$ & Sig. \\
\hline \multirow[t]{4}{*}{1} & (Constant) & .461 & .653 & & .707 & .488 \\
\hline & $\begin{array}{l}\text { Ukuran } \\
\text { Perusahaan }\end{array}$ & -.022 & .042 & -.159 & -.517 & .611 \\
\hline & Likuiditas & .478 & .305 & .490 & 1.568 & .133 \\
\hline & Profitabilitas & -.022 & .028 & -.202 & -.770 & .450 \\
\hline
\end{tabular}

Sumber : Data diolah dengan SPSS16

Berdasarkan tabel diatas dapat diketahui persamaan regresi linear berganda sebagai berikut :

$\mathrm{Y}=0,461-0,022 \mathrm{X} 1+0,478 \mathrm{X} 2-0,022 \mathrm{X} 3+\mathrm{e}$

Dari persamaan tersebut dapat berarti bahwa nilai konstanta sebesar 0,461. Nilai koefisien ini menunjukkan apabila tidak ada perubahan pada variabel ukuran perusahaan, likuiditas dan profitabilitas maka struktur modal mengalami kenaikan sebesar 0,461 .

Dari persamaan tersebut dapat berarti bahwa koefisien variabel Ukuran Perusahaan (X1) sebesar -0,022 yang berarti memperlihatkan arah hubungan negative (berlawanan) antara struktur modal. Tanda negative menunjukkan jika variabel ukuran perusahaan (X1) naik sebesar satu satuan maka struktur modal akan turun sebesar -0,022 dengan asumsi variabel independen lainnya konstan.

Koefiisen untuk variabel Likuiditas (X2) sebesar 0,478 yang memperlihatkan arah hubungan positif (searah) antara Likuiditas (X2) dengan struktur modal. Tanda positif memperlihatkan jika variable Likuiditas (X2) naik sebesar satu satuan maka struktur modal akan naik sebesar 0,478 dengan asumsi variabel independen lainnya konstan.

Koefiisen untuk variabel Profitabilitas (X3) sebesar -0,022 yang menunjukkan arah hubungan negative (berlawanan) antara Profitabilitas (X3) dengan struktur modal. Tanda negative menandakan jika variable Profitabilitas (X3) naik sebesar satu satuan maka struktur modal akan turun sebesar -0,022 dengan asumsi variabel independen lainnya konstan.

\section{Uji Hipotesis}

Uji F (Simultan)

Dari hasil olahan data dapat diketahui hasil uji F pada tabel 8 sebagai berikut: 


\section{Tabel 8}

Hasil Uji F (Simultan)

ANOVA ${ }^{b}$

\begin{tabular}{llrrrrr}
\hline \multicolumn{2}{l}{ Model } & \multicolumn{2}{c}{ Sum of } & & & \\
\hline & Squares & Df & Mean Square & F & \multicolumn{1}{c}{ Sig. } \\
\hline 1 & Regression & 1.799 & 3 & .600 & 1.073 & $.383^{\mathrm{a}}$ \\
& Residual & 11.175 & 20 & .559 & & \\
& Total & 12.974 & 23 & & & \\
\hline
\end{tabular}

\section{Sumber: Data diolah dengan SPSS16}

Berdasarkan tabel diatas hasil hasil $\mathrm{Uji}_{\mathrm{F}} \mathrm{hitung}_{\mathrm{i}}$ sebesar 1.073 dengan nilai signifikan sebesar $0,383>0,05$ dari semua variabel, hal tersebut mengidentifikasikan bahwa semua variabel independen tidak signifikan terhadap struktur modal. Dan mempunyai nilai $F_{\text {tabel }}$ sebesar 3,10. Karena $F_{\text {hitung }}<F_{\text {tabel }}$ maka $\mathrm{H}_{1}$ ditolak dan $\mathrm{H}_{0}$ diterima.

\section{Uji t (Persial)}

Untuk mengetahui uji t (Persial) dapat dilihat pada tabel di bawah ini :

\section{Tabel 9}

\section{Hasil Uji t (Persial)}

\begin{tabular}{llrr} 
Model & $\mathrm{t}$ & Sig. & \\
\hline 1 & (Constant) & .707 & .488 \\
& Ukuran Perusahaan & -.517 & .611 \\
& Likuiditas & 1.568 & .133 \\
& Profitabilitas & -.770 & .450 \\
\hline
\end{tabular}

Sumber: Data diolah dengan SPSS16

Dari tabel diatas dapat disimpulkan sebagai berikut :

1. Uji persial variabel ukuran perusahaan (X1) terhadap variabel struktur modal dari hasil pengkajian yang dilakukan dan nampak pada $t_{\text {hitung }}$ sebesar $-0,517$ dengan nilai tidak signifikan 0,611 dari tingkat alpha 0,05 dan $\mathrm{t}_{\text {tabel }}$ sebesar 2,074. Artinya bahwa ukuran perusahaan berpengaruh negatif dan tidak signifikan. Dan Karena $t_{\text {hitung }}<t_{\text {tabel }}$ sehingga hipotesis ditolak.

2. Uji persial variabel likuiditas (X2) terhadap variabel struktur modal dari hasil pengkajian yang dilakukan dan nampak pada $t_{\text {hitung }}$ sebesar 1,568 dengan nilai tidak signifikan 0,133 dari tingkat alpha 0,05 dan t tabel sebesar 2,074. Artinya bahwa likuiditas (X2) berpengaruh positif dan tidak signifikan. Dan Karena $t_{\text {hitung }}<t_{\text {tabel }}$ sehingga hipotesis ditolak.

3. Uji persial variabel profitabilitas (X3) terhadap variabel struktur modal dari hasil pengkajian yang dilakukan dan nampak pada $t_{\text {hitung }}$ sebesar $-0,770$ dengan nilai tidak signifikan 0,450 dari tingkat alpha 0,05 dan $\mathrm{t}_{\text {tabel }}$ sebesar 2,074. Artinya bahwa profitabilitas (X3) berpengaruh negatif dan tidak signifikan. Karena $t_{\text {hitung }}<t_{\text {tabel }}$ sehingga hipotesis ditolak. 


\section{Analisis Koefisien Determinasi Multiple (R2)}

Adjusted R-squared dipakai sebagai pengukuran seberapa banyak proporsi variasi dari variabel independen secara bersama - sama untuk mempengaruhi variabel dependen. Dari pengolah data ditemukan nilai Adjusted $R$-squared $0,90 \%$ variabel independen ukuran perusahaan (Size), likuiditas (CR) dan profitabilitas (ROA) memepnagruhi struktur modal sebesar $0,90 \%$ sedangkan sisanya $99,10 \%$ dipengaruhi faktor lain.

\section{PEMBAHASAN}

\section{Pengaruh Struktur Modal terhadap Ukuran Perusahaan}

Berdasarkan hasil uji hipotesis variabel ukuran perusahaan (X1) terhadap struktur modal memiliki hasil $\mathrm{t}$ hitung $-0,517$ sedangkan nilai signifikan tersebut sebesar 0,611 > $\alpha=0,05$, hal ini artinya variabel ukuran perusahaan (X1) berpengaruh negatif dan tidak signifikan terhadap struktur modal.

Menurut Asymmetric information theory membuktikan bahwa perusahaan besar memilikii tingkat kekurangan informasi dibandingkan perusahaan kecil. Perusahaan besar mendapat perolehan biaya ekuitas sangat rendah dibandingkan perusahaan kecil, sehingga perusahaan besar banyak memakain ekuitas dibandingkan perusahaan kecil. Namun, perusahaan dengan ukuran besar akan mempunyai akses besar untuk memperoleh sumber pendanaan dari banyak sumber, untuk menapatkan pinjaman dari kreditur lebih mudah sebab perusahaan dengan ukuran besar mempunyai profitabilitas besar agar dapat memimpin persaingan industri.

Hasil pengkajian ini didukung oleh (Insiroh, 2014) yang melakukan penelitian mengenai pengaruh profitabilitas, ukuran perusahaan, pertumbuhan aset, dan struktur aset terhadap struktur modal yang mendapatkan bahwa ukuran perusahaan (size) tidak memiliki pengaruh signifikan terhadap struktur modal. Hasil penelitian (Krisnanda \& Wiksuana, 2015) tentang pengaruh ukuran perusahaan, pertumbuhan penjualan dan Non Debt Tax Shield terhadap struktur modal pada perusahaan telekomunnikasi di Bursa Efek Indonesia mendapatkan bahwa ukuran perusahaan berpengaruh negatif dan tidak signifikan terhadap struktur modal pada perusahaan telekomunikasi di Bursa Efek Indonesia periode 2010-2013.

\section{Pengaruh Likuiditas terhadap Struktur Modal}

Berdasarkan hasil uji hipotesis variabel likuiditas (X2) terhadap struktur modal memiliki hasil $\mathrm{t}$ hitung 1.568 sedangkan nilai signifikan tersebut sebesar $0,133>\alpha=0,05$, hal ini artinya variabel likuiditas (X2) berpengaruh positif dan tidak signifikan terhadap struktur modal.

Hal tersebut berarti sesuai dengan Pecking Order Theory yaitu di mana perusahaan dengan likuiditas tinggi memperlihatkan bahwa aset lancar yang dipunyai lebih tinggi daripada kewajiban lancar. Perusahaan dengan likuiditas tinggi mempunyai dana internal lebih besar, sehingga perusahaan lebih memakai dana internalnya dahulu untuk membayar investasinya sebelum memakai pembayaran eksternal dari hutang.

Hasil penelitian ini didukung oleh penelitian Vina Ratna dan Saifudin (2012) dalam (Santoso \& Priantinah, n.d.) yaitu Pengaruh Profitabilitas, Ukuran Perusahaan, Struktur Aktiva, likuiditas dan Growth Opportunity Terhadap Struktur Modal Perusahaan menunjukkann bahwa Likuiditas berpengaruh negatif 
terhadap Struktur Modal. Hasil dari pengkajian ini juga sesuai dengan hasil penelitian oleh Sakti (2002) dan Sabir (2012) dalam (Kartika, I Komang Sunarta. Dana, 2015) yang meneliti Analisis Pengaruh Profitabilitas, Ukuran Perusahaan, dan Tingkat Pertumbuhan terhadap Struktur Modal Perusahaan Food and Beverages yang Terdaftar di Bursa Efek Indonesia yang menyebutkan likuiditas mempunyai pengaruh positif terhadap struktur modal apabila semakin tinggi likuiditas maka struktur modalnya juga meningkat.

\section{Pengaruh Profitabilitas terhadap Struktur Modal}

Berdasarkan hasil uji hipotesis variabel profitabilitas (X3) terhadap struktur modal memiliki hasil $t$ hitung sebesar $-0,770$ dengan sig. variabel profitabilitas $0,450>0,05$, hal ini artinya variabel profitabilitas (X3) berpengaruh negatif dan tidak signifikan terhadap struktur modal.

Berdasarkan teori pecking order perusahaan dengan tingkat profitabilitas banyak justru tingkat hutangnya sedikit, karena perusahaan dengan profitabilitas tinggi mempunyai sumber pendanaan sangat baik.

Profitabilitas (X3) tidak berpengaruh signifikan berarti pada masa periode pengamatan perusahaan mengalami penurunan hasil penjualan, sehingga mengakibatkan laba yang didapatkan mengalami penurunan. Kreditur dan investor lebih berorientasi pada rencana bisnis jangka panjang dengan harapan kondisi perekonomian akan segera membaik, sesuai dengan penelitian oleh Defia (2014) dalam (Sari \& Oetomo, 2016) yang meneliti Pengaruh Profitabilitas, Likuiditas, Pertumbuhan Aset dan Ukuran Perusahaan terhadap struktur Modal menunjukkan bahwa Profitabilitas (ROA) berpengaruh negatif tetapi tidak signifikan terhadap struktur modal. Dan sesuia penelitian dari (Suryaman, 2010) dalam penelitainnya tentang Pengaruh Profitabilitas, Struktur Aktiva dan Ukuran Perusahaan terhadap Struktur Modal pada Perusahaan Manufaktur yang terdaftar di Bursa Efek Indonesia Tahun 2009 - 2012 yang membuktikan bahwa variabel profitabilitas berpengaruh negatif dan tidak signifikan terhadap struktur modal.

\section{SIMPULAN}

Kesimpulan dari penelitian ini adalah ukuran perusahaan (X1) berpengaruh negatif dan tidak signifkan terhadap struktur modal pada perusahaan otomotif yang terdaftar di Bursa Efek Indonesia karena semakin kecil perusahaan, maka lebih berkait pada hutang untuk sumber pendanaannya. Likuiditas (X2) berpengaruh positif dan tidak signifikan terhadap struktur modal pada perusahaan otomotif yang terdaftar di Bursa Efek Indonesia, karena apabila perusahaan memiliki likuiditas tinggi artinya bahwa aset lancer banyak dari pada kewajiban lancar. Profitabilitas (X3) berpengaruh negatif dan tidak signifikan terhadap struktur modal pada perusahaan otomotif yang terdaftar di BEI, karena apabila profitabilitas (X3) perusahaan mengalami kenaikan, maka struktur modal perusahaan sebaliknya terjadi penurunan dikarenakan profit tersebut digunakan sebagai pelunasan utang jangka panjang yang dipunyai perusahaan.

\section{UCAPAN TERIMAKASIH}

Ucapan terima kasih untuk Bapak Febryandhie Ananda, SE, M.Si selaku Ketua Sekolah Tinggi Ekonomi Keuangan Perbankan dan Pembanguan (STIE"KBP" Padang) beserta Staf Pimpinan, Karyawan dan Karyawati di STIE"KBP” Padang. Ibu Aminar Sutra Dewi, SE,M.Si selaku pembimbing dalam 
penulisan skripsi ini. Bapak dan Ibu Dosen STIE"KBP" Padang yang telah membantu penulis selama menuntut ilmu yang bermanfaat kepada penulis selama perkuliahan. Teman - teman dan pihak - pihak lain yang membantu penulis dalam menyelesaikan skrispi ini yang tidak dapat penulis sebutkan satu persatu namanya.

\section{DAFTAR PUSTAKA}

Afriyeni, A., \& Fernos, J. (2019). Analisis Pengaruh Faktor Determinan Terhadap Economic Value Added Dan Implikasinya Terhadap Pergerakan Harga Saham Properti Di Bursa Efek Indonesia. https://doi.org/10.31219/osf.io/qf5nm

Afriyeni, A., \& Marlius, D. (2017). Analisis Pengaruh Harga Saham Perdana Terhadap Abnormal Return Yang Diterima Investor Studi Pada Bursa Efek Indonesia. https://doi.org/10.31219/osf.io/8z7hx

Afriyeni, A., \& Marlius, D. (2018). Analisis Pengaruh Informasi Prospektus Perusahaan Terhadap Initial Return Saham Pada Pasar Perdana Di Bursa Efek Indonesia. https://doi.org/10.31219/osf.io/kt6c4

Afriyeni, A., \& Marlius, D. (2019). Analisis Faktor-Faktor Yang Berpengaruh Terhadap Ketepatan Waktu Penyampaian Laporan Keuangan Pada Perusahaan Yang Listing Di Bursa Efek Indonesia. https://doi.org/10.31219/osf.io/rv4qf

Afriyeni, A., \& Marlius, D. (2019). Analisis Tingkat Pengembalian Dan Risiko Investasi (Studi Pada Industri Manufaktur Yang Terdaftar Di Bursa Efek Indonesia). https://doi.org/10.31219/osf.io/cfb92

Bhawa, I. B. D., \& S, M. R. D. (2015). Pengaruh ukuran perusahaan, likuiditas, profitabilitas, dan risiko bisnis terhadap struktur modal perusahaan farmasi, 4(7), 1949-1966. https://doi.org/ISSN:2302-8912

Dewi, A. S. (2015). Pengaruh Informasi Kas Dan Earning PER Share Terhadap Return Saham Perusahaan Manufaktur di Bursa Efek Indonesia. Riset Manajemen Dan Akuntansi,2, 1-7.

Fernando, R., \& Dewi, A. S. (2018). Pengaruh CAR, BOPO, NPL, NIM, dan LDR Terhadap Roa Pada Perusahaan Di Sektor Perbankan Yang Terdaftar Di Bei Periode 2012-2016. https://doi.org/10.31219/osf.io/k3w69

Furi, V. R., \& Saifudin. (2012). Faktot - Faktor Yang Mempengaruhi Struktur Modal ( Studi Empiris Pada Perusahaan Manufaktur yang Terdaftar di BEI Tahun 2009 - 2010 ), 1(2), 49-62. https://doi.org/ISSN : 2301-9328

Hudan, Y., Deannes Isynuwardhana S.E, M. ., \& Dedik Triyanto.S.E., M. A. (2016). Pengaruh Profitabilitas, Likuiditas dan Ukuran Perusahaan terhadap Struktur Modal (Studi pada Perusahaan Pertambangan Sektor Batubara yang 
terdaftar di Bursa Efek Indonesia Tahun 2011 - 2015), 3(2), 1596-1603. https://doi.org/ISSN : 2355-9357

Ichwan, F. Y., \& Widyawati, D. (2015). Pengaruh Ukuran Perusahaan, Struktur Aktiva dan Profitabilitas Terhadap Struktur Modal, 4(6), 1-19.

Insiroh, L. (2014). Pengaruh Profitabilitas, Ukuran Perusahaan, Pertumbuhan Aset, Struktur Aset Terhadap Struktur Modal, 2.

Kartika, I Komang Sunarta. Dana, M. (2015). Analisis Pengaruh Profitabilitas, Likuiditas, Ukuran Perusahaan, Dan Tingkat Pertumbuhan Terhadap Struktur Modal Perusahaan Food And Beverages Yang Terdaftar Di Bursa Efek Indonesia. E Jurnal Ekonomi Dan Bisnis Universitas Udayana, 606625.

Sari, D. P., \& Dewi, A. S. (2018). Pengaruh Likuiditas Dan Solvabilitas Terhadap Profitabilitas Pada Perusahaan Makanan Dan Minuman Yang Terdaftar Di Bursa Efek Indonesia Periode 2013-2015. https://doi.org/10.31219/osf.io/n75gr 